\title{
Fisher communities in transition: understanding change from a livelihood perspective in Chilika Lagoon, India
}

\author{
Prateep Kumar Nayak
}

Correspondence: pnayak@uwaterloo.ca

School of Environment, Enterprise and Development, Faculty of Environment, University of Waterloo, Waterloo, ON N2L 3G1, Canada

\begin{abstract}
The sustainable livelihood framework is a widely used approach to analyze changes in rural livelihoods, especially in resource dependent communities. The framework emphasizes that given a certain situation where the livelihood context, resources and institutions remain favourable, livelihood strategies carried out by people could possibly lead to two different outcomes. One, the results of livelihood strategies will produce sustainable outcomes providing affected households respite from the impacts of livelihood loss. Two, there is a possibility that resulting outcomes may not be sufficient to reverse livelihood crisis and may not necessarily result in sustainable livelihood because of the complexities, uncertainties and multilevel drivers associated with it. This paper aims to evaluate both these possibilities through use of empirical data to clarify factors and conditions that may impede sustainable livelihood outcomes despite well planned strategies. It highlights that availability of more resources (or capitals) do not necessarily contribute to more robust livelihood strategies or outcomes. Using the case of small scale fishery-based livelihood system of Chilika Lagoon, Bay of Bengal in the East coast of India, this paper suggests that the relationship between livelihood shocks and stresses, capitals, institutions and livelihood strategies is circular and not linear. Extensive household and village level survey data are used to examine the processes of social-ecological change in Chilika from a livelihood perspective. It describes how through changes in context, resources and institutions, fishers in Chilika responded to the livelihood crisis, and how various strategies were used. It further examines the extent to which the outcomes of the strategies contributed to making fisher livelihoods sustainable. Conclusions drawn suggest that the outcomes of the livelihood crisis and responses from Chilika fishers have resulted in higher levels of their disconnection from the Lagoon and their marginalization. The multiplicity of ways through which fishers in Chilika perceive their livelihood suggest that livelihood in resource dependent communities, such as Chilika small-scale fisheries, is multidimensional and far more complex and dynamic than often perceived. Further innovations in approaches and tools will help better understand livelihood challenges and make related outcomes sustainable.
\end{abstract}

\section{Introduction}

The sustainable livelihood framework has remained a useful approach to analyze changes in rural livelihoods, especially in resource dependent communities. The framework highlights that given a particular context, characterised by political, socio-

(c) The Author(s). 2017 Open Access This article is distributed under the terms of the Creative Commons Attribution 4.0 International License (http://creativecommons.org/licenses/by/4.0/), which permits unrestricted use, distribution, and reproduction in any medium, provided you give appropriate credit to the original author(s) and the source, provide a link to the Creative Commons license, and indicate if changes were made. 
economic, ecological, historical settings and conditions, a combination of livelihood resources (e.g., different types of 'capitals') can contribute to the ability of resource users to follow a variety of livelihood strategies (e.g., intensification, extensification, diversification and migration) leads to certain outcomes. In this process, institutional processes which mediate the ability to carry out such strategies and achieve (or not) such outcomes (Scoones 1998). The sustainable livelihood framework and its many iterations are mainly based on five interacting factors: context, resources, institutions, strategies and outcomes (Ellis 2000a, b). The framework emphasizes that given a certain situation where the livelihood context, resources and institutions remain favourable, the livelihood strategies carried out by people could possibly lead to two different outcomes. One, the results of such livelihood strategies will produce sustainable outcomes providing the households respite from ongoing impacts of livelihood loss. Two, there is a possibility that resulting outcomes may not be sufficient to reverse livelihood crisis and may not necessarily result in sustainable livelihood because of the complexities and uncertainties associated with it as well as the many multilevel drivers with their influential roles. This paper aims to evaluate both these possibilities through use of empirical data to clarify factors and conditions that may impede sustainable livelihood outcomes despite well planned strategies. It highlights that availability of more resources (or capitals) do not necessarily contribute to more robust livelihood strategies or outcomes. In fact, the paper highlights with field data that the relationship between livelihood shocks and stresses, capitals, institutions and livelihood strategies is circular and not linear.

Chambers and Conway (1992:6) suggested that "a livelihood is sustainable when it can cope with and recover from stresses and shocks, maintain or enhance its capabilities, assets and entitlements, while not undermining the natural resource base. "Allison and Horemans (2006:759) state that "a livelihood is sustainable if people are able to maintain or improve their standard of living related to well-being and income or other human development goals, reduce their vulnerability to external shocks and trends, and ensure their activities are compatible with maintaining the natural resource base." These definitions of a sustainable livelihood are important but also limited to the extent that they sound prescriptive. Absent are any clear ideas on how livelihoods "can cope with and recover from stresses and shocks" (Marschke and Berkes 2006:1) within the given context and conditions outlined in the definitions.

Two sets of livelihood literature provide further insights into this gap. One, much work in the area of livelihood adaptation has focused mainly on the strategies that can help respond to livelihood crisis. This include work on various livelihood strategies such as diversification (Ellis 2000a, b; Carswell 2002; Cinner and Bodin 2010; Iiyama et al. 2007), intensification (Carswell 1997; Tomich et al. 2000; Fabinyi. 2010; Raut et al. 2010; Tuyen et al., 2010), extensification (Orr and Mwale 2001; Gebrul and Beyene 2012; Eneyew and Bekele. 2012), and migration (de Haan, 1999; de Adger et al. 2002; Waddington, 2003; Thieme, 2008). Two, a second set of literature has developed to address the importance of political, socio-economic, ecological, historical contexts, drivers and institutional processes influencing livelihood outcomes (REFS). However, a search for literature (using google scholar) suggests that there is comparatively scant literature that primarily focus on connecting sustainable livelihood strategies and political, historical and institutional contexts of livelihoods. This suggests to an apparent gap in the literature which this paper aims to address through the use of 
an empirical case study from the east coast of India along with extensive field data on livelihoods.

Nonetheless, livelihood approach remains a powerful approach that warns us about 1) the nature and extent of complexity involved in achieving sustainable livelihoods and 2) the possibility that livelihood strategies, influenced by changes in context, resources and institutions, may rarely result in sustainable livelihoods. This paper uses a sustainable livelihood framework to further probe these challenging issues by using extensive household level livelihood data in two sample villages of Chilika Lagoon, Bay of Bengal, India. In particular, role played by tiger shrimp aquaculture under the influence of international market prices and opening of a new sea mouth in undermining ongoing fishery-based livelihood system in Chilika have been discussed. Using the adverse impacts of the two drivers, the paper describes how through changes in context, resources and institutions, the fishers in Chilika dealt with the livelihood crisis, and how various strategies were used. It further examines the extent to which the outcomes of the strategies contributed to making fisher livelihoods sustainable. Conclusions drawn, based on fisher experiences in Chilika lagoon, suggest that the resulting trends from the livelihood crisis and a series of responses from the Chilika fishers have contributed to their own marginalization. It identifies a number of condition under which shocks to the system undermined existing capitals of fishers, existing institutions and consequently livelihood strategies. Nevertheless, this paper recognises that the sustainable livelihoods framework provides an analytical framework to understand livelihoods and is not a remedy for sustainable development.

\section{Study area and methods}

\section{Staying alive: current livelihood crisis in Chilika}

Chilika lagoon, also called Chilika Lake, is the largest lagoon in India and one of the largest in Asia, with an area of $1165 \mathrm{~km} 2$. It is in Odisha State on the east coast of India on the Bay of Bengal, Indian Ocean. Chilika is a Ramsar site wetland of global conservation importance, and a productive area with a fish fauna adapted to a mix of freshwater and seawater that characterises lagoon ecosystems (Nayak and Berkes 2010). There are about 337 villages around the lagoon, 150 of them being fisher villages. The estimated fisher population of the area is about 400,000 in about 40,000 fisher households. The fishers are caste-based, meaning that the fishery consists of traditional fisher groups whose vocation is identified by their membership in certain Hindu castes. Like many coastal lagoons around the world, Chilika lagoon has been facing a series of problems resulting in serious degradation of its social and ecological base with longterm impacts on the lives and livelihoods of the fishers.

Several drivers have contributed to the process of livelihood loss for fishers in Chilika. However, two causes stand out as major drivers of changes in livelihood. Those are extensive tiger shrimp aquaculture starting in the early 1980's and creation of an artificially dredged new sea mouth with the Bay of Bengal in 2001. These two drivers had differential impacts on the social-political, economic, and ecological aspects of fishers' lives. While aquaculture directly influenced access rights and village fishery cooperatives through largescale encroachment of customary fishing areas (Samal 2007; Sekhar 2004; Pattanaik 2007; Adduci 2009; Nayak 2011; Nayak and Berkes 2010, 2011; Sahu 
2014), the new sea mouth inadvertently impacted the species composition, fish habitat and productivity of the Lagoon (Dujovny 2009; Sahu 2014; Nayak 2014; Nayak et al. 2014, 2015). The two drivers acted synergistically, the sea mouth impact amplifying fisher livelihood disruption due to aquaculture expansion, and the two together resulted in the loss of fisher livelihoods as a major outcome (Nayak and Berkes 2014).

Since the 1970s, a steady increase in the global demand for fish and a consistent decline in the total yield from capture fishery sources have brought aquaculture development to the forefront (Delgado et al. 2003; Pradhan and Flaherty 2008; Marshall 2001). In the case of shrimp, growing consumer demand in the North America, European countries and Japan gave rise to high international prices (Neiland et al. 2001; Bene 2005) thereby luring many countries into export-oriented shrimp aquaculture. The international market for shrimp and prawn developed in the 1970s; prawn in India that had little value previously became "pink gold" (Kurien 1992). Intensive shrimp aquaculture started in the late 1970s in India and gained momentum in the mid-1980s, putting India among the leading shrimp exporting countries in the world. The total value of export earnings from shrimp in the year 2004 was US\$715 million (FAO 2006) and it has gone up since then. Chilika Lagoon, which was a natural area for tiger shrimp (Penaeus monodon), caught on to the trend in the early 1980s, as investors and policy makers found it highly suitable for intensive shrimp aquaculture. As the international price of tiger shrimps spiralled upwards, the stakes for the non-fishers in Chilika became formidable (Pattanaik 2007). Soon shrimp aquaculture became a major driver of change in Chilika Lagoon. Its development spread with great speed and intensity throughout the Lagoon. Out of a total of 140 fisher villages surveyed, 135 stated that they were adversely impacted by shrimp aquaculture in Chilika.

By 1990s, Chilika lagoon was experiencing heavy siltation that blocked the inflow and outflow of water to the Bay of Bengal. The existing opening with the sea was barely functional creating further problem in hydrological interaction between the sea and the lagoon. Instead of a project to renovate the existing sea mouth, the State Government decided to create an artificial opening in 2001 to establish a direct connection between the Bay of Bengal and the main basin of the lagoon. Apparently, the decision to create the new opening was based on scientific advice but soon it became clear that the location of the new sea mouth was wrong because it was created at a place which increased the intensity of water inflow and outflow with daily high and low tides. In contrast to the old sea mouth where the daily inflows and outflows were buffered by the presence of channels and islands, the new sea mouth, efficiently engineered to flush out sediments, allowed in too much sea water (Nayak and Berkes 2010). This inadvertently resulted in ecological and livelihood impacts. On the ecological front many changes were reported by the fishers: (1) Disturbance of the salinity regime and the fresh water-salt water balance, (2) Changes in the nature of water inflow and outflow, and the force of water during high and low tides, (3) Increase in sand infestation especially in the lagoon outer channel areas that are in proximity to the new sea mouth, (4) Random changes in depth of water, (5) Sudden appearance of what local people call "sea creatures": stingray (Trygon sephen), octopus (Cabreana octopus), jelly fish (Cnidaria scyphozoa aurelia), barnacles (Balanus glandula), and others invasive sea species causing physical alteration in lagoon habitat. The most significant impact of these changes was felt through an increase in the variability, uncertainty, and unpredictability of events 
associated with the lagoon, such as fishing seasons by species, with impacts on fish production and livelihoods (Nayak 2014).

As a direct result of lagoon degradation and other impacts linked to the drivers, fish yields and fisher incomes declined, which was serious enough to make fishing livelihoods no longer viable in some villages, with negative trends in all fisher villages. Cumulative impact of multiple impacts from the drivers contributed to severe food insecurity (see details in Results section). As per the results of village level survey, onethird of adult fishers were occupationally displaced from fishing by the end of 2009 . Fishers migrated to distant urban centers as unskilled or daily wage workers (see section on migration for further details). However, human costs of this crisis seems invisible to decision-makers as the State Labour Department reported zero migration from Chilika during the same time.

Capture fishery areas traditionally controlled by caste-based fishers were encroached and converted into shrimp farms. Ninety-one percent of the fisher villages that held government leases to fishing areas reported ongoing encroachment. Increased fishing area encroachment resulted in frequent resource disputes, caste conflicts, and court cases. Significant policy changes to justify aquaculture-based fisheries and to extend fishing rights to non-fishers were introduced starting in 1991. However, these policies were successfully challenged in courts (State and Federal) in 1993 and 1996 which banned shrimp aquaculture in and around the Lagoon. In practice, court decisions could not be enforced given intense power and politics across all levels. Consequently, fishers lost access to their fishing areas and entitlements resulting in sweeping changes in resource rights regime. Fishers' economic status and incomes fell to an all-time low, and most of them ended up in a serious livelihood crisis (see results section below for details). Village fisher cooperatives and other local fisheries institutions collapsed. Most village fisher cooperatives went out of business with some $89 \%$ became dormant or non-functional. Locally crafted, multilevel institutional arrangement (e.g., Chilika Fisher Federation, Caste Panchayats/Assembly, Central Fishermen Cooperative Marketing Society) virtually disappeared contributing to a steady erosion of local level fisher controls of lagoon fisheries.

Several other drivers also contributed to the livelihood crisis. These included policy and institutional changes around fishing area lease and lagoon management, influence of regional and global shrimp and fish market price, and environmental/climatic factors relating to the interactions of the Lagoon with the Bay of Bengal (e.g., tidal movement, cyclones) and Eastern Ghats mountain ranges (e.g., forest degradation leading to lagoon siltation and restricted fresh water inflow). Societies often adapt to change, but in the Chilika case, the speed of change overwhelmed local fishers' ability to respond, and there were far-reaching impacts on their livelihoods. The details of the changes and their impacts form the crux of the analysis in this paper which is further supported with household and village level data collected through a longitudinal study.

\section{Study methods}

Data used in this paper primarily comes from a set of three different surveys involving fisher households and villages: $(1)$ household $(N=160)$ survey in two selected fisher villages (2007 - 2009), (2) monthly household-level $(N=30)$ monitoring $(2008-2010)$, 
and (3) general survey in fisher villages $(N=150)(2009-2011)$. The three surveys aimed to collect data on livelihood changes at the household and village/community level through the use of different questionnaires. I started with a rapid reconnaissance survey of about 60 fisher and non-fisher villages around Chilika Lagoon to get a broader perspective of the livelihood situation. Discussions with a number of NGOs, research institutions, government departments, Chilika Fishers' Federation and key individuals added to this experience. Based on some preliminary findings, a list of nine criteria (Table 1) were drawn for selection of two representative study villages, and a household survey questionnaire was developed, field-tested and revised before being used. Not all criteria directly applied to both study villages, i.e., if one village represented being impacted by the sea mouth as a criteria, the same criteria was used to select the second village which was not directly impacted by the sea mouth. The use of the nine criteria helped with selecting two representative villages which also provided two different contexts for analysis.

\section{Designing the survey formats}

The three survey questionnaires were prepared at different stages of the research and all of them were in the local Odiya language, which most villagers are well versed with. First, a household survey questionnaire was prepared based on the outcomes of the reconnaissance survey and it covered areas ranging from demography and livelihoods to migration and village institutions. The first draft of the questionnaire contained openended questions to maintain a free flow of answers rather than restricting households to pick from a given list of responses. The questionnaire went through rigorous fieldtesting in six shortlisted villages and necessary revisions were done before it was implemented in the two selected study villages, Berhampur and Badakul (Fig. 1).

Second, following the household survey I set up a household level monthly livelihood monitoring to understand how fisher households respond to ongoing crises, the nature of these crises and emerging trends. While the household survey was effective in capturing the status of households at a given point in time and its preceding period, the household monitoring was able to capture the ongoing livelihood and survival processes in fisher households. If household survey clarified what had gone wrong and how, the monitoring exercise showed how things were progressing over a period of time. With this in mind, a household livelihood monitoring questionnaire was development towards the end of the household survey.

Third, a general survey in all the 150 fisher villages of Chilika was conducted and, as a first step, a survey format was prepared with the help of fisher friends. An important

Table 1 Criteria used for selection of study villages

- Village inhabited by people who are fishers by caste

- Village where fishing has been the primary or only source of income

- Village which is impacted by the new sea mouth

- Village where lease of fishing area related problem exists

- Village where encroachment of customary fishing areas exists

- Village impacted by shrimp aquaculture

- Village with loss of fishery-based livelihoods

- Village which is facing large-scale out-migration

- Village where fisheries cooperative has broken down and other fisheries institutions are in a flux 


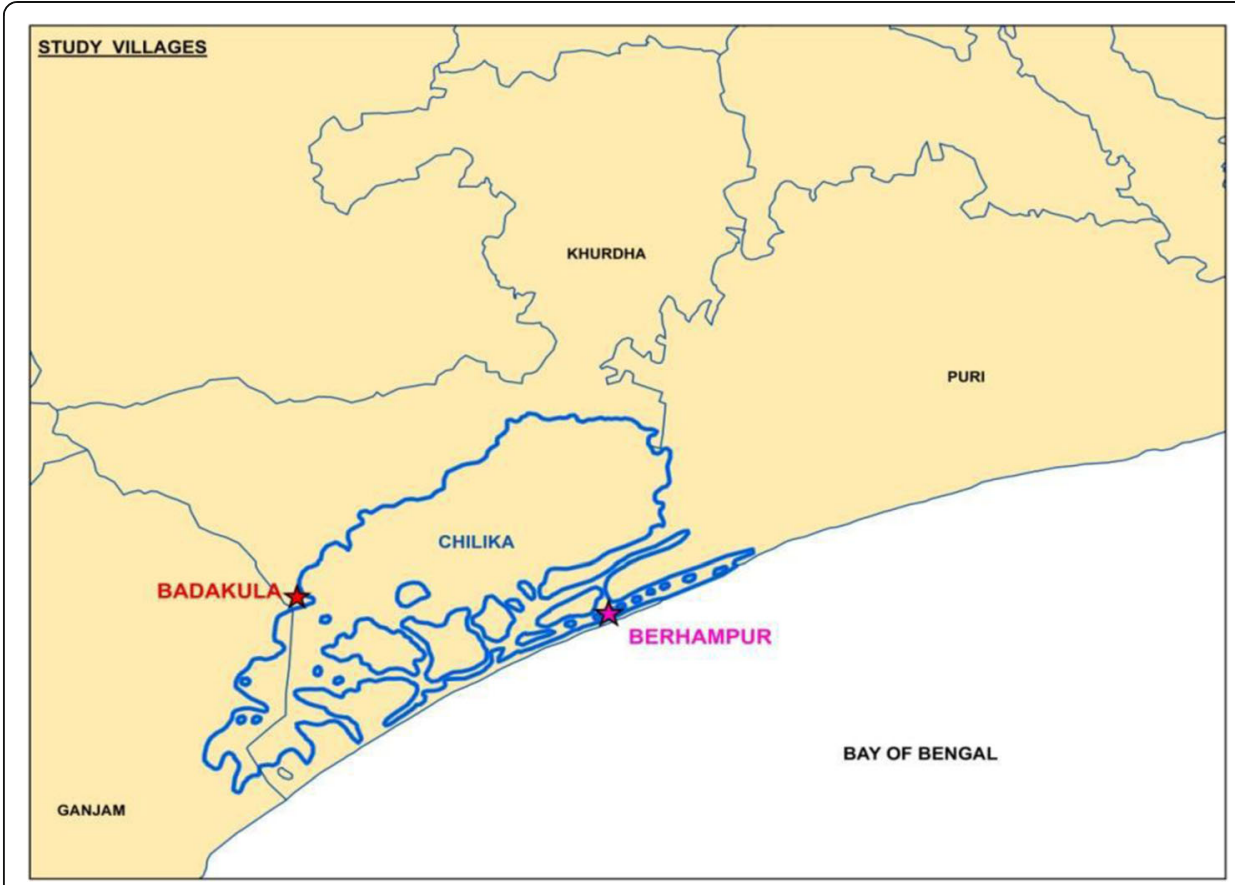

Fig. 1 Location of study villages - Berhampur and Badakul - in Chilika Lagoon

difference between the household survey and general village survey was that the former was implemented at the household level in the two study villages whereas the latter was used to gather the overall views of each fisher village through village meetings or meetings of the village committee. For the household survey, one survey questionnaire per each sample household was used and only one survey questionnaire was used per each fisher village for the village survey. It covered areas ranging from total village fishing area and the extent of their encroachment to the number of fishers on migration and the status of village fish cooperative.

\section{Conducting the household and village surveys}

I started household survey work first in Berhampur village, followed by Badakul. In Berhampur, a village with 285 fisher households, 35\% households were sampled, and in Badakul, a village with 60 fisher households, $100 \%$ sampling was done. Selection of the study households in Berhampur was done through either random or purposive sampling with an intension to include households with a range of socio-economic and livelihood profiles. Households which had a history of migration and those with family members still on migration at the time of the survey were given priority in both the villages. This does not mean households who did not have a similar history were excluded. Similarly, households that had already abandoned fishing were purposively included along with those that had higher rates of loans and those who had successfully taken up alternate livelihood activities. On the whole, an attempt was made to include a combination of households to represent the diversity of question areas included in the livelihood survey questionnaire. The household survey questionnaires were orally administered by myself and a community researcher. It was not focused on the head of the households only, as is done in many other surveys. Rather, an attempt was made to 
include as many family members as possible, including women and youth, in the process of filling out the survey questionnaires. As a result, only $20 \%$ of surveys were conducted with men only. About $80 \%$ of the household surveys, in both villages, were conducted with women members of the family or a mix of men, women and youth members. Out of this $80 \%, 33 \%$ were conducted with women only. Part of the reason for higher participation of women in the household survey was the absence of male members due to migration. Moreover, repeat visits to a number of surveyed households were made to crosscheck with women household members if they were not originally a part of the household survey.

For the purpose of household livelihood monitoring, 20 households in Berhampur and ten households in Badakul were purposively selected. All 30 households were picked from the list of already surveyed households. Attention was given to factors such as migration, loan transactions, still in fishing or out of fishing as a livelihood source and health issues in selecting households for monitoring. Monthly monitoring was conducted using a questionnaire. Household-level livelihood monitoring continued for a period of 18 months spanning January 2008 to June 2009.

The scale (all fisher villages) at which the general village survey was planned required extensive collaboration with the Fisher Federation and other local contact persons. The idea was to reach out to all the fisher villages in Chilika so that a broader picture of the livelihood situation in the Lagoon could be drawn. Each village was given one questionnaire to fill out in larger village meetings or in a meeting of the village committee. Several methods were used to complete this survey work: 1) the research team visited a number of villages, explained what needed to be done, handed over a survey questionnaire along with a return postal envelope, and asked them to send it back when ready; 2) village representatives attending the Fisher Federation meetings were given the responsibility to complete this survey and send it back using the return postal envelope; 3 ) the research team was also able to complete a few surveys during our visit to some villages; 4 ) in certain cases questionnaires were sent through someone from another village and follow up was done over the phone until the survey was returned by post. There was overwhelming response to the general village survey as we could cover all the 150 fisher villages. Several village representatives called me over phone to discuss about the survey and many of them wanted to see the outcomes appearing in the newspapers or brought to the notice of the government.

In addition to the surveys, selected data for this paper come from semi-structured interviews, focus groups, multi-stakeholder consultations, and secondary sources including both village records and policy documents.

\section{Results: fishers' approach to livelihood crisis in Chilika}

With the onset of the livelihood crisis the fishers took up several strategies to deal with it. A set of five strategies and their sub-strategies were recorded in the case of Chilika: (1) coping for subsistence, (2) intensification, (3) extensification, (4) diversification and (5) out-migration. I discuss each of the livelihood strategies with their sub-strategies in the following section. Some of these livelihood strategies have already been used by Chilika fishers in the past, such as taking loans, mortgage and purchase on credit from village shop. Other strategies recorded are completely new (e.g. migration from Berhampur and others under intensification and expansion). For some of the previously 
used strategies, their intensity and frequency have increased during the crisis. The sequence in which fishers' livelihood strategies are discussed in the following section follows the actual order by which the fishers took up different strategies in both study villages.

\section{Coping strategies for subsistence}

It is difficult to go fishing on an empty stomach. Only when I have arranged firewood for the chullaha (wooden stove) and rice for the pots to cook food, hunger of my family will calm down and I will have the peace of mind to go fishing. In a situation where we lack daily supplies to cook food, I do whatever options are readily available. Who has the time to think about the future?

\section{["Petare dana padile sina macha maribu. Chuli ku katha and handi ku Chäula} jogyila pare jaee paribarara bhoka mentiba and mu santi re macha maribaku jayee paribi. Epari paristhiti re hatapahantare jaha padila taku adori tapare bhabisyata katha chinta karibi"] Abhimanyu Jena, ${ }^{1}$ Fisher, Berhampur village, July 2007.

Abhimanyu's statement clarifies that for poor households a livelihood crisis often impacts the existing support system for subsistence. Consider that $100 \%$ of households in both the study villages said they preferred to make arrangements to address immediate subsistence needs on a priority basis before any long term strategy was even considered. This would ensure some level of basic livelihood security in maintaining access to food, health care, education for children and social relationships. As Table 2 illustrates, most of these subsistence strategies were relatively easy to access and doable; however not without long-term implications. The following section tries to tease out some of these nuances: how a number of households fell into a vicious debt trap and the resulting financial uncertainties.

Accessing financial capital had a significant role in determining how a household could deal effectively with some of the initial challenges posed by livelihood crisis. It was also a factor for preparing the household to undertake more long-term approaches to move from coping to other livelihood strategies. In their pursuit of immediate coping strategies, fisher households in Chilika mostly went after accessing available

Table 2 Coping strategies for livelihood subsistence

\begin{tabular}{ll}
\hline Sub-strategy & Activity \\
\hline Take loans and credit & - Consumption loans from multiple sources \\
& - Cash advance from fish trader \\
& - Credit from village grocery store \\
Mortgage and sell assets & - Mortgage and sell of household items \\
& - Mortgage or sell fishing equipment, including boats \\
Change in food habits & - Low quality and quantity of food \\
Discontinue children's education & - Some sent elder children to work \\
Rearrange personal and professional relationships & - Break away from joint family \\
& - Send elder children to live with relatives in other villages \\
& - Change fish trader or take a second or third trader \\
& - Discontinue participation in Fisher Federation and NGO \\
& activities including rallies and movements
\end{tabular}


financial capital in the form of loans, advances and credits (Table 2). Abhimanyu Jena of Berhampur went to the money lender for small cash loans on each of those days when he failed to get a marketable catch. With a falling catch size he now does this for more than 10 days a month. Abhimanyu considers cash loans as critical to ensure a supply of food to his family, whilst trying out other options for a more reliable income. Considering that $97 \%$ of households in Berhampur and $98 \%$ of households in Badakul said they experienced regular food shortage, and most households (100\% in Berhampur and $98 \%$ in Badakul) said they depended on cash loans as a coping strategy, it is hardly surprising that most other households in both villages do what Abhimanyu has opted to (Table 3).

Table 3 shows that households in both the villages took staggering amounts of cash loans in the recent years. A majority of the households (67\% in Berhampur and 55\% in Badakul) have taken loans that range from 50 to 200 thousand INR over a duration of about 5 years. Another 15\% in Berhampur and 9\% in Badakul have even gone up to 500 thousand INR during the same period. The contrast between these figures on loan amounts and the total household incomes (85\% households in Berhampur and 62\% households in Badakul earned less than INR 15,000 during 2007 - 2008) indicates that a majority of fishing households in both villages have taken loans several times higher than what they actually earn. In other words, the ratio between household income and the amount of loan is a total mismatch. This also points towards the inability of households to repay cash loans leading to the accumulation of higher loan amounts and pressure of higher interest payments within a short period of time.

What makes repayment and the clearing of loans nearly impossible is the rate of interest and the purpose for which loans are taken. Available data suggest that $90 \%$ of households in Berhampur and 92\% of households in Badakul have agreed to pay an interest rate ranging from 36 to $60 \%$ per annum. A smaller number of households even pay an interest rate as high as $120 \%$ per annum (Table 3). "I find it difficult to even repay five percent of the annual interest on my loan amount every year. The principal amount is turning into a nightmare for me", said Hadu Behera of Badakul village. What adds to this nightmare is the purpose for which most fisher households have taken loans. Table 4 suggests that a substantial part of the total loan is for consumption or/ and other unproductive purposes. Loans for productive purposes like buying fishing

Table 3 Status of households in terms of indebtedness

\begin{tabular}{lll}
\hline Percentage of HH & Berhampur (in \%) & Badakul (in \%) \\
\hline Experienced food shortage & 97 & 98 \\
Depended on cash loans & 100 & 98 \\
Held cash loans between 50 and $200 \mathrm{~K}(\mathrm{INR})^{\mathrm{a}}$ & 67 & 55 \\
Held cash loans between 200 and $500 \mathrm{~K}(\mathrm{INR})$ & 15 & 9 \\
Paid interest at 36\% - 60\% per annum ${ }^{\mathrm{b}}$ & 90 & 82 \\
Paid interest at 120\% per annum & 10 & 98 \\
With outstanding loans & 100 & 62 \\
With outstanding loans exceeding 50 K (INR) & 79 & \\
\hline a 1 USD $=66$ INR (2016 exchange rates) & \\
bThe interest rates cited here indicates the rate of interests fishers were paying at the time of field study during 2007 - 2009, \\
and recent follow up studies shows the rates of interest continues to be the same
\end{tabular}


Table 4 Purpose for which fishers have taken loans

\begin{tabular}{lll}
\hline Purpose for loan & Berhampur (in \%) & Badakul (\%) \\
\hline Food for HH consumption & 95 & 50 \\
Health/Hospitalization & 43 & 44 \\
Cultural ceremonies & 64 & 17 \\
Repay existing loans & 55 & 47 \\
Buy fishing equipment & 80 & 35 \\
House repairs & 10 & 4 \\
Marriage & 54 & 17 \\
Ceremony associated with death & 31 & 17 \\
Repay fish trader's advance & 4 & 13 \\
Children's education & 56 & 19 \\
Buy/repair boats & 33 & 15 \\
Other purposes & 13 & 25 \\
\hline
\end{tabular}

Note: Questions allowed for multiple responses

gears and boats do not yield much return due to low fish production and the frequent loss of fishing gear to theft and natural calamity.

Chapala Behera of Badakul observed, "The majority of these loans are from local areas (informal sources) that have an interest in perpetuating the cycle of debt; allows us an easy entry but hardly a way to come out of it. Taking loan means getting into a chakravieu (vicious cycle). Table 3 offers evidence to support Chapala's statement: of those who took loans, $100 \%$ of households in Berhampur and $98 \%$ of households in Badakul have current outstanding loans; $79 \%$ of them in Berhampur and $62 \%$ in Badakul have outstanding loans exceeding 50 thousand INR."

Another form of loan is interest-free cash advances from the fish traders to whom each fisher household is attached. Households get into verbal agreements with fish traders in lieu of a bulk amount as cash advance and remain committed to sell their everyday catch to the same trader. While the advance money stays with the fisher household as long as they sell fish to the trader, the fishers are also allowed to request more cash advances at times of crisis. Consequently, 100\% of households in Berhampur and $76 \%$ of households in Badakul reported that they held cash advances from fish traders, and that they had taken new advances in the recent years, especially after the livelihood crisis emerged. Though it is interest-free, there are often strings attached to these advances, and these are discussed further in the subsequent section on livelihood outcomes.

Once faced with a livelihood crisis, many fisher households have either: 1) increased their number of fish traders up to three; 2) changed their existing fish traders; 3) taken new advances from their existing fish traders; or, 4) tried a combination of the three as coping strategies. First, those who have two or three traders did it by accepting separate traders for each adult member within the same household (e.g., the father and each of the sons having different traders). This meant that both the father and his son got separate advances from the fish traders which helped to meet the financial needs of the household. I learnt that most fisher households used this as a strategy to have more interest free advances instead of taking high interest-based loans. A number of households have also linked up with crab traders, in addition to their existing fish traders, 
because they have started crab fishing to promote an alternative source of income due to the decrease in fish and shrimp. This gets them additional cash advances.

Second, those who changed traders did so mainly because they were not able to maintain a steady supply of fish and shrimp to the trader due to falling production levels. At the same time, it was not possible for the fisher households to return the cash advance to the fish trader. Most households received notice from fish traders to return their interest free advances or face confiscation of their fishing equipment, including boats and motor engines. In such situations many fisher households took up new fish traders and got fresh cash advances; part of this cash was used to repay advances owing from the previous fish trader and the rest of it came in handy during crisis situations for other household expenses. Third, a good number of households, those with more male fishers and/or with household members able to send remittances from migration, were able to combine all three strategies with regard to advances from fish traders.

Even though loans and advances constitute a significant basis of cash flow to the fisher households, they also engage in other crisis management strategies when faced with livelihood related uncertainties. Table 5 illustrates that fishing households have mortgaged personal assets (36\% in Berhampur and 45\% in Badakul), sold fishing boats (27\% in Berhampur and 14\% in Badakul) and sold other personal possessions including fishing gear (98\% in Berhampur and $71 \%$ in Badakul) as an immediate coping strategy. In addition, buying food on credit from the village stores is practised by $88 \%$ of households in Berhampur and 87\% of households in Badakul. A number of households in both study villages explained that they preferred to pay back the credit at the village stores on a priority basis because of their continuous dependence on these stores for everyday food stuffs.

Livelihood crisis has important impacts on the consumption levels of households (See Table 3 for food shortages and Table 4 for consumption loans). Consequently, compromise on the quality and quantity of food came up as an immediate coping strategy that was adopted by a majority of fisher households in both villages. About $70 \%$ of households in Berhampur and 76\% of households in Badakul have changed their food habits as a strategy to minimize frequent food shortages for the family. A directly related aspect concerns health problems in fisher households, as instances of health crises have shot up significantly in the last less than a decade. Three important sets of data from the household surveys draw our attention to this fact: 1) $49 \%$ of households in Berhampur and $72 \%$ of households in Badakul cited health and hospitalisation as one of their three major heads of expenditure; 2) 50\% of households in Berhampur and 70\% of households in Badakul mentioned health problem and hospitalization as one of their four important reasons for financial crisis; 3) $49 \%$ of households in Berhampur and $74 \%$ of households in Badakul had health and hospital expenses as one of the six

Table 5 Status of households regarding credit and mortgage

\begin{tabular}{lll}
\hline Percentage of $\mathrm{HH}$ & Berhampur & Badakul \\
\hline Took cash advance from fish trader & 100 & 76 \\
Mortgaged personal assets & 36 & 45 \\
Sold fishing boats & 27 & 14 \\
Sold fishing gears and other possessions & 98 & 71 \\
Bought grocery on credit from village shop & 88 & 87 \\
\hline
\end{tabular}


important reasons for which they took out loans. In tandem with these findings, the monthly household monitoring data in the two villages showed that on average $46 \%$ of the households took loans, on any given month, for health-related crises. In the absence of any baseline date on health, households' comparative analysis between their previous and current health situations were considered.

A health crisis is not new to the fishers of Chilika. However, there are two recent trends associated with the health crisis that make it different from the past: 1) the frequency and intensity of health crisis have increased; and, 2) fishers now increasingly talk about mental or emotional health as a key element of health crisis. An increase in the frequency of health problems is attributed to changes in the quality of food and the problems in mental health situation result from excessive stress due to livelihood uncertainties, as was reported by $59 \%$ of households in Berhampur and $46 \%$ of households in Badakul. The absence of proper health care facilities and inadequate government support for health care has adversely contributed to this crisis. For Berhampur village, the nearest government hospital is at a distance of $40 \mathrm{~km}$ and for Badakul it is at about a distance of $10 \mathrm{~km}$. However, fishers have to pay for expenses towards their treatment, including medicines. There is also a general perception that government health facility is comparatively less reliable and has many inconveniences associated with it. Consequently, fishers largely depend on private health care facilities by spending excessive amounts of money. This explains the linkages between the financial problems and the health problems explained in the preceding paragraph. Even if some of the health problems were not directly related to the ongoing change processes in Chilika, it adversely contributed to the further worsening of health status of fishers due to deteriorating income levels, food and nutrition, living conditions and other factors.

Expenses on children's education formed a significant component of the financial profile of fisher households in the two study villages: $39 \%$ of households in Berhampur and $59 \%$ of households in Badakul mentioned children education as one of the reasons for the financial crisis; 22\% of households in Berhampur and 34\% of households in Badakul discontinued their children education as a coping strategy; $57 \%$ of households in Berhampur and 33\% of households in Badakul opted to take loans for continuing their children's education. Even then, a significant number of households in both study villages preferred to stop sending their children to school in order to minimize the financial burden, and because the elder children could engage in income generating activities. This was evident in the high dropout rates (51\%) and low enrolment (39\%) in the village school of Berhampur. The school register shows that over the past 7 years there has been a 70\% fall in students who appear for the High School Examination. As Kunti Jena of Berhampur village explained:

Four of our five children are in the village primary school and they generally go hungry on the Sundays and holidays because the school is closed and there is no 'mid-day meal' ${ }^{2}$ available. I struggle to bring them books and school dress, but I am happy that they get to eat at least a meal most days in a week........ do not know how we are going to manage once they cross primary school.

Kunti's husband is on migration to Kerala and he had not sent back any money to the family. Like Kunti's children, the mid-day meal brings young children in the village 
to the primary school; if not for education, then definitely for a meal. Consequently, there is relatively better attendance in primary school classes but as children approach middle and high school they tend to drop out.

\section{Intensification/extensification strategies}

I have already exhausted the existing sources of cash loans and advances, and no one wants to give me loans anymore even with higher interest rates. I cannot leave the village because my wife and two kids will be left alone. Neither I have land to undertake vegetable cultivation or tree plantation as some others in the village do, nor can I start a village shop due to lack of finance. I am ready to sell my labour for daily wage but opportunities are really not available. I now plan to go back to fishing again and step up my efforts there in all possible ways. Prahallda Jena, Fisher, Berhampur village, November 2008.

For many fishers intensification is the only livelihood strategy available as they cannot migrate and a lack of start-up capital restricting diversification. Intensification becomes imperative as most of these households approach a point of saturation in terms of pursuing immediate coping strategies for subsistence. Fish traders are often forthcoming if households want to stay on fishing, or want to come back to it after periods of staying away from fishing, so that a steady supply of fish can be maintained. This also works as an incentive for many households to cling on to fishing and gradually intensify and extensify their efforts, even though this may not be sufficient.

In both Berhampur and Badakul, the bulk of intensification occurs within the fishing sector. Table 6 outlines various sub-strategies and activities pursued by fishers for intensification in both the study villages. As a strategy, the fishers intensify their fishing activities to make the most of resources available under the given social-ecological conditions.

Modernisation of fishing is a fairly new phenomenon in Chilika (no more than four decades old) and started as a result of the interest in shrimp aquaculture. Prior to this time the fishers followed various traditional practices of fishing including hand woven

Table 6 Intensification as livelihood strategy

\begin{tabular}{|c|c|}
\hline Sub-strategy & Activity \\
\hline Gear selection and use & $\begin{array}{l}\text { - Select synthetic nets of fine mess size } \\
\text { - Use fishing nets that are catch intensive } \\
\text { - Pick fishing gears that can be used in a variety of locations: } \\
\text { shallower and deeper parts of Lagoon, and some in the sea }\end{array}$ \\
\hline $\begin{array}{l}\text { Stop seasonal fishing (no longer following } \\
\text { traditional fishing seasons) }\end{array}$ & - Year-round fishing of all available species \\
\hline No size restriction & $\begin{array}{l}\text { - Catch all available sizes } \\
\text { - Catch post-larval shrimp for sell to aquaculture ponds }\end{array}$ \\
\hline No time and space restriction & $\begin{array}{l}\text { - Fish anytime anywhere } \\
\text { - Semi-permanent and permanent nets }\end{array}$ \\
\hline No species restriction & - Catch all available species \\
\hline $\begin{array}{l}\text { Focus on single species } \\
\text { (determined by availability, price, and market) }\end{array}$ & $\begin{array}{l}\text { - Shrimp fishing } \\
\text { - Specific fish species } \\
\text { - Crab fishing }\end{array}$ \\
\hline Aquaculture & - Productive Lagoon areas under intensive shrimp farming \\
\hline
\end{tabular}


cotton nets and the use of several locally available materials like bamboo, rattan, etc. With intensification most of the customary systems of fishing have changed significantly. The diversity of customary fishing practices, and their associated methods and techniques, were gradually replaced by a few dominant methods using synthetic gillnets and trammel nets (locally known as khanda jala or "disco nets"). With fine mess size and durability these nets proved to be exceptionally catch-intensive and became a frontrunner in the process of mechanisation of fishing in Chilika. With a variety of synthetic fishing gears available to them, fishers are able to select gears that can help in intensive fishing at different locations within the Lagoon - shallow water, deep water, near the river mouths, close to the sea mouth and, to a limited extent, in the Bay of Bengal too. The replacement of traditional fishing boats with motorized boats also formed a significant part of the intensification strategy in Chilika.

Discussions with elderly fishers revealed that fishing in Chilika followed a strict seasonal routine before the onset of the livelihood crisis. Even though there were some overlaps, the year was distinctly divided into fish (July - October), shrimp (March June) and crab (November - February) fishing seasons. After the onset of the livelihood crisis, intensification strategies included interfering with this seasonality in order to maximize catches. The new techniques enabled households to fish year round, disregarding seasonality. Most of these fish species are now caught throughout the 12 months of the year, in contrast to the original seasonality of only 2 to 4 months.

Earlier, under a regime of customary fishing, norms evolved by the communities offered safeguards to different species and sizes of fish, and specified the time and location of fishing. However, fishing intensification brought in strategies that by default removed the customary restrictions on the size, species, time and location for fishing. Fishers now compete with each other to catch all available sizes and species of fish in their drive to increase (intensify) production.

After a number of trips on fishing boats and several visits to the shallow water trammel nets I learnt that at least $40 \%$ of the catch consisted of juvenile fish and crabs. The observation was further confirmed with several trips to local fish markets and landing stations where one can see undersized fish and crabs for sale, including out-of-season fish species. "If I do not catch these fish someone else will pick them up. I do not want to be a loser when incomes are already so low", replied Deepak, a young fisher from Balabhadrapur village, whom I accompanied on a fishing trip. ${ }^{3}$

Restrictions on the time and location of fishing, which depended on tidal and fish movements, have now been replaced with semi-permanent or permanent nets that sit in the Lagoon day and night. Fishing intensification in certain cases also involves nighttime fishing. More than $90 \%$ of the fisher households in both the study villages own nets that can be placed in the Lagoon on a semi-permanent (long term) basis.

Intensification through targeting single species is practiced differently in different fisher villages. In Berhampur, crab fishing has been taken up by $33 \%$ of households as an alternate source of income in recent years. Previously, most of these households focused on catching fish and shrimp. This change was further confirmed by the fact that a comparable percentage of households have recently signed up with crab traders. Crabs enjoy a healthy demand, both in the local as well as export markets, and crab fishing also requires relatively low investment. In Badakul, the entire village now focuses primarily on patua fishing (fingerlings of one particular species) for about 8 months in a year. They have 
developed nets of fine mess size (made out of mosquito nets) in order to catch fingerlings of patua fish, which is considered suitable both as raw and processed dry fish.

Even though their numbers are not significant, several households also engage in catching post-larval shrimp. An exact estimate on the number of households engaged in picking post-larval shrimp could not be obtained simply because a lot of households did not want to report it, perhaps because it is technically illegal. These small shrimps are easy to catch and they are often sold to aquaculture ponds at a good price. Postlarval fishing is practiced by many households throughout Chilika Lagoon as part of their intensification strategy that focuses on exploiting target species. This strategy is largely influenced by the existing market demand, sustained by growing aquaculture in the Lagoon, including price. "It fetches a really good price compared to catching fish which is time consuming, high on investments and offers low returns," said Bikram Jena of Berhampur village, who spent part of his fishing time catching shrimp postlarvae before he left on migration.

The connections between the sectors (aquaculture and post-larval fishing), and the resulting dependence of some fishers on aquaculture, could create divisions among fishers. However, this was not what the study revealed, which may be attributed to three factors: (1) Fisher households that pick post-larvae also include the majority of those with their own aquaculture ponds, with almost all retaining the post-larval shrimp for their own use, they do not sell to other/non-fisher aquaculture owners; (2) those households without their own aquaculture ponds engage in this activity only occasionally and seasonally, and the incomes from this source do not constitute a significant percentage of their total annual income (roughly estimated at $<5 \%$ ); and, (3) the owners of the big ponds are not dependent on these fishers, rather, employing private labourers hired from outside Chilika area and also from non-fisher villages in Chilika for more organised collection of post-larval shrimp within the Lagoon. Moreover, postlarval collection is also a major income activity for people in a large number of nonfisher villages (several times more so than those in fisher villages) around Chilika. Therefore, the big aquaculture owners are not relying on the supply of post-larval shrimp by caste-based fishers. It is evident from the three factors that the nature of engagement by fishers in post-larvae collection and their limited dependence on the big aquaculture farms is unlikely to constitute a significant factor that can create political divisions among fishers on the issue of their opposition to aquaculture. Inversely, the significant involvement of non-fishers in post-larvae collection acts as a counter-force to the opposition to aquaculture by fishers, especially given that in the Chilika area as a whole, fishers are in the minority, about 200,000 out of 500,000 (40\%).

Only a few selected fisher households use shrimp aquaculture both as an intensification and extensification strategy. Not everyone is able to afford the high capital investment and labour inputs, and the capacity to operate successfully given the power and political dynamics that surround shrimp aquaculture activities in the Lagoon. Consequently, it is not surprising that only $5 \%$ of households in Berhampur and $2 \%$ of households in Badakul have taken up small-scale shrimp aquaculture as an alternate strategy for livelihoods. About an equal number of households said they had undertaken shrimp aquaculture a few years back but had to stop as it turned unmanageable due to diseases in the shrimp ponds and the continuous loss of profit. Intensification in the form of aquaculture includes holding productive areas within the Lagoon as shrimp ponds for 
increasing production of tiger shrimps. Extensification is practised as a strategy to include more productive areas of the Lagoon under shrimp aquaculture and to also convert strategically located farm lands into shrimp ponds. Other strategies of extensification are listed in Table 7.

A sharp decline in fish stock, an enormous loss of customary fishing areas to encroachment, and a lack of access to existing fishing grounds due to ongoing conflicts have forced households to look for alternate areas for fishing. This has been reported elsewhere (Pattanaik 2007, Dujovny, 2009, Nayak and Berkes 2010). This implies that average fisher households now travel longer distances and often have to fish outside the village's customary fishing boundaries. At these locations, fishers not only face strong competition from other fishers but they also run the risk of fishing within the territory of another village. This is considered a form of extensification that results in fishers now competing to capture several strategic areas within the Lagoon as alternate fishing grounds - fishing near the sea and river mouths, and numerous channels that are key fish movement routes, areas near uninhabited smaller islands as they provide camping ground for fishers. The number of fishers who engage in deep water fishing has also increased significantly in recent years.

At a time when fishing areas have become scarce, extensification of fishing efforts is a growing strategy for desperate fisher households. I found many instances of fishers across villages organizing into small fishing groups, to pool available resources, and engage in fishing at different strategic locations within the Lagoon, including deep waters. I interacted with a number of these groups who operate semi-permanent or permanent fishing camps far inside the Lagoon, preferably near smaller islands. My discussions with village fish traders in Berhampur informed me that they have started buying sea fish in order to make up for the short supply of Lagoon fish in recent years. At least two fish traders in Berhampur now seasonally employ sea-going fishers whom they hire on contract from South India. A few other villages (like Arakhakuda) located close to the Bay of Bengal are in the process of gradually extending their fishing efforts into the sea.

Table 7 Extensification as a livelihood strategy

\begin{tabular}{|c|c|}
\hline Sub-strategy & Activity \\
\hline Travel long distances for fishing & $\begin{array}{l}\text { - Fishing outside traditional fishing boundaries } \\
\text { - Fishing in others' territories }\end{array}$ \\
\hline Capture strategic areas for fishing & $\begin{array}{l}\text { - Fishing near sea and river mouths, channels that are key fish movement } \\
\text { routes } \\
\text { - Fishing in deeper parts of the Lagoon }\end{array}$ \\
\hline Look beyond the Lagoon & $\begin{array}{l}\text { - Traders buying sea fish } \\
\text { - Traders employing sea going fishers }\end{array}$ \\
\hline Catch all available species & - Increase the number of species in the catch basket without any limit \\
\hline Product extensification & $\begin{array}{l}\text { - Sale of freshwater fish } \\
\text { - Dry fish of all possible species }\end{array}$ \\
\hline Target non-fish species & - Fish to bird: Poach/hunt migratory birds (very limited) \\
\hline More organized groups & $\begin{array}{l}\text { - Permanent fishing camps inside Lagoon } \\
\text { - Formation of fishing groups across villages }\end{array}$ \\
\hline Aquaculture & $\begin{array}{l}\text { - Extensive shrimp farming: Take more and more Lagoon areas under } \\
\text { shrimp aquaculture }\end{array}$ \\
\hline
\end{tabular}


Thus, extensification as a strategy has multiple manifestations in the context of Chilika. There is evidence that people from certain villages engage in poaching migratory birds for sale, and market channels now connect even the occasional catch of a stingray directly with the restaurants selling soup in Hong Kong and Singapore. Fresh water fish, mainly Rohu (Labeo rohita), is now an integral part of the bulk of fish sold at the stores of many Chilika Lagoon fish traders, as well as the fish sold by women who have taken up fish vending. This confirms that fishers in Chilika are using product extensification as a livelihood strategy in addition to their efforts to increase the unit area for fishing within the Lagoon.

\section{Diversification as livelihood strategy}

Due to a general lack of options and start up finances, livelihood diversification has not been a very successful strategy in Chilika. Table 8 lists the various livelihood diversification strategies of Chilika fishers.

Table 9 illustrates that even after years of livelihood crisis and a staggering loss of incomes from fishing, most households in both study villages continue to retain fishing either as their primary or the only livelihood occupation. In this context, it is interesting to observe what makes diversification of livelihood activities difficult in the context of Chilika fishers? Since these are fishers by caste, who have for generations not done anything else other than fishing, they tend to lack the necessary skills and resources to take up alternate livelihood activities. Even though locally available options for livelihood are limited, what is available does not fit the existing skill levels of the fisher households. This makes the diversification of livelihood activities outside the fishing sector, or not linked to Lagoon fishing, difficult.

Diversification remains a "mental block" for several fisher households who consider fishing as a caste or cultural activity, a way of life, rather than an economic pursuit. This complicates livelihood choices further in terms of people moving out of fishing to non-fishing activities. The "mental block" not only comes from a sense of cultural connection to the Lagoon but also results from their fear of permanently moving away from customary fishing as a way of life. Many old fishers think that by being born into a fishing caste, they are solemnly tied to fishing as their identity. However, community

Table 8 Diversification as a livelihood strategy

\begin{tabular}{|c|c|}
\hline Sub-strategy & Activity \\
\hline Activities linked to primary occupation (fishing) & $\begin{array}{l}\text { - Fish selling - both Lagoon and freshwater fish (women) } \\
\text { - Dry fish (women) } \\
\text { - Employment on fishing boats (men) } \\
\text { - Employment at shrimp aquaculture farms (men) } \\
\text { - Employment as boat driver: Fishing and tourist boats (men) }\end{array}$ \\
\hline $\begin{array}{l}\text { Use of available natural capital (private land assets): } \\
\text { Creating future assets for income generation }\end{array}$ & $\begin{array}{l}\text { - Making orchards } \\
\text { - Vegetable cultivation } \\
\text { - Tree plantation on homestead: Coconut and fruits }\end{array}$ \\
\hline Host of non-fishing occupations & $\begin{array}{l}\text { - Selling fruit from fruit trees at backyard } \\
\text { - Open retail shops in the village } \\
\text { - Daily wage } \\
\text { - Salaried private jobs } \\
\text { - Rearing cows, buffalos and goats }\end{array}$ \\
\hline Engage women and children in income generation & $\begin{array}{l}\text { - Women engage in several occupations } \\
\text { - Adolescent children engage in livelihood related occupations }\end{array}$ \\
\hline
\end{tabular}


Table 9 Percentage of households with fishing either as primary or only occupation

\begin{tabular}{llllll}
\hline Villages & \multicolumn{2}{l}{ Fishing as primary occupation } & & \multicolumn{2}{l}{ Fishing as only occupation } \\
\cline { 2 - 3 } & Yes & No & & Yes & No \\
\hline Berhampur & 96 & 1 & 27 & 70 \\
Badakul & 48 & 7 & 13 & 42 \\
\hline
\end{tabular}

members, who leave fishing and head to regional urban centers, have set off a process of cultural change which in turn is weakening the traditional notion of a "fisher community" as defined by caste. "Some migrant fishers now find it hard to express "who they are' and 'which caste or community they belong to'. Consequently, the pride felt by individuals who belonged to the fisher community has been replaced by a deep sense of alienation, where occupationally displaced fishers do not feel they belong to either world - neither Chilika nor the city where they work as wage labourers (Robson and Nayak 2010:275)."

Even though there are limits to the success of diversification as a livelihood strategy, $44 \%$ of households in Berhampur and $68 \%$ of households in Badakul said they had taken up additional income generating activities to support their livelihoods. This is a significant change in Berhampur where fishing was the only livelihood occupation for $86 \%$ of households prior to 2000. In Badakul the process of livelihood diversification started about 20 years back, before which more than $91 \%$ of households followed fishing as the only occupation to support their livelihoods.

As part of their strategy for livelihood diversification fisher households take up several activities which are discussed here under three broad categories. First, households engage in a number of activities that are linked to their primary or only occupation, which is fishing. While men have opted for employment on fishing boats, jobs at shrimp aquaculture farms, work as drivers on fishing and tourist boats, women have taken up dry fish processing and fish vending as a diversification strategy. However, data indicates that while men in both villages have adopted fishing related diversification as a livelihood strategy, it is only women in Badakul who have accepted similar strategies. The reasons for this are discussed further in the livelihoods outcome sections.

Second, a number of households chose a host of non-fishing activities as part of livelihood diversification strategy. Activities such as front door retail shops, shops in the village or nearby market places, daily wage, salaried jobs (private and government), the sale of fruits from household trees and raising animals are part of this strategy. Third, several households make use of available natural capital, primarily land, in an effort to create future assets for income generation. If successful it can offer a stable source of income to a small number of households in the fisher villages even though this is more of a long-term strategy for livelihood diversification. Activities under this strategy include commercial tree plantations on small patches of available land, and planting fruit trees such as coconut, mango, guava, lemon on homestead.

\section{Migration as livelihood strategy}

In this section, migration is discussed in terms of both out-migration and migrant work. Outmigration generally means moving away, whereas migrant workers retain 
homes in the community and return on a regular basis. In the two study villages, there is not a single evidence of "moving away" (either individually or with family), and in each of the cases where migration has occurred, migrant fishers have retained homes and families in the community and they return on a regular basis, some more frequently than others. Therefore, it would mean that all cases of migration in Chilika involve migrant work. However, a significant number of those who return from migrant work do not maintain any links with the village fishery institution and the resource base, especially young fishers.

As such, Robson and Nayak (2010) have used the term "circular migration" and/or "temporary migration" to explain this short-term nature of fishers' work related movements (migrant work) and the term "permanent migration" to denote what is referred to as "out migration" or "moving away". In addition to the important criteria of (1) whether retaining homes/families and (2) returning on a regular basis they also used the criteria of (3) whether the migrant fishers have been able to maintain their affiliations with the village fishery institution and (4) their livelihood linkages with the resource in order to determine the nature of migration either as circular/temporary or permanent. In other words, if a migrant fisher does both (3) and (4), in addition to (1) and (2), then it indicates a level of disconnection denoting some sense of "moving away" (hence "out-migration"). This understanding would mean that Chilika case has both migrant workers (circular or temporary migration) and out-migration (permanent migration).

In Berhampur village, all five sons of Sudhakara Jena are on out-migration (as of June 2012) to different places in Tamil Nadu and Kerala. One of his sons first went in 2005 and four others followed him within the next 1 year. Sudhakar is 70 years of age and, in the absence of his sons, his family has given up fishing since 2006. His sons send him money which he uses to repay the huge debt that had accumulated over the years. $\mathrm{He}$ is also rebuilding the once unfinished family home in preparation for getting his sons married so that each of them can have a room with their wives. The prosperity of Sudhakar's family no longer rests on fishing but rather, in the continued absence of his sons from home, by migration (Interview with Sudhakar Jena and his wife Bimala Jena during household survey, August, 2007 and information from monthly household monitoring).

In Badakul village, Balmiki Behara's only son went to Kolkata in 1999 in search of a better income so that his family can move out of the debt trap and no longer struggle for income from a failing fishing occupation. Nine years on, Balmiki's son continues to live in Kolkata with his wife and one child, and struggles more than ever before to make a living with a monthly income of 1500 INR as a private security guard, an amount which is not even enough to rent a tiny room in the city. Balmiki regularly sends money to his son so that at least his grandchild does not go hungry. The family has lost most of its assets, and its debts have increased manifold. The only option for Balmiki is to hang on to the fast declining fisheries as his wife continues to toil in her multiple roles as a fish vendor, seasonal wage labour and borrower from the thrift and credit group ((Interview with Balmiki Behera during household survey, January 2008, and follow up meetings until June 2009).

Pramod Behera of Badakul migrated to Chennai for the first time in 1997 as a construction labour. He returned after a couple of months realizing that he could do this 
for a few months per year and it was not a good idea to stay away from home indefinitely. Ten years later Pramod manages to combine seasonal migration with seasonal fishing and other local activities to earn a livelihood for his family. He takes up new loans but he is also able to repay some of that in time, and he hopes to continue his current livelihood strategies with seasonal migration as an important component of it. (Interview with Pramoda Behera during household survey, August, 2007 and information from monthly household monitoring).

In Berhampur village, Taranisen Jena's eldest of the three sons went on migration to Kerala in 2007. He returned back within a couple of months after being hospitalized for sickness. Taranisen spent 5000 INR on his treatment, an amount which his son could not even earn during his entire period of migration. On top of that he had taken a loan of 3000 INR to meet the costs towards his son's migration. For Taranisen, household migration as a livelihood strategy has not yielded desired results. However, the family expects to benefit from out-migration as two other younger sons prepare to migrate (Interview with Taranisen Jena, his wife Kumudi Jena and two sons during household survey, August, 2007, and follow up meetings).

With varying degrees of success, fisher households in Chilika have continued to depend on out-migration as a livelihood strategy (Table 10) ever since the emergence of the crisis. Fifty-three percent of households in Berhampur and 31\% of households in Badakul have pursued migration as a livelihood strategy since 2001, which is considered a landmark year in terms of loss of fish production due to the opening of a new sea mouth.

While none of the households in Berhampur had a history of migration prior to 2001, in Badakul 75\% of the households had already used migration as a livelihood strategy as early as 1993. In contrast, $42 \%$ of households in Berhampur that migrated did so in the year 2007. This suggests that migration is a relatively new phenomenon in Berhampur as compared to Badakul where it started about two decades back. The difference in the trend of migration in these two villages resulted from the fact that the loss of fish production as well as local livelihoods occurred in different time periods. This is discussed further in the subsequent section on livelihood outcomes.

Although households continue to migrate, not all of them have done so on a longterm basis. Table 11 suggests that the migrating members of fisher households return after a few months or years for reasons ranging from health issues to the nonavailability of work to exploitation at the workplace. In Berhampur alone, where most of the migration began during 2005-2007, 27\% of households had members who had migrated but returned to the village by 2008 . Considering pre-1993 as the start of migration in Badakul, $91 \%$ of the households that used migration as a strategy for livelihood had returned to the village by 2008 .

Table 10 Migration as livelihood strategy

\begin{tabular}{ll}
\hline Sub-strategy & Activity \\
\hline Long-term migration & Migrate for indefinite period of time \\
Seasonal migration & $\begin{array}{l}\text { Seasonal migration (for wage labour) becoming part of the annual cycle } \\
\text { of livelihoods }\end{array}$ \\
Migrate within the state & Very few migrate within Odisha \\
Migrate outside the state & Most migrate outside Odisha to major cities in Southern and Western India \\
\hline
\end{tabular}


Table 11 Reasons for returning from out-migration

\begin{tabular}{lllllll}
\hline Villages & $\begin{array}{l}\text { Health } \\
\text { Problem }\end{array}$ & $\begin{array}{l}\text { Language } \\
\text { Problem }\end{array}$ & $\begin{array}{l}\text { Hard } \\
\text { work }\end{array}$ & $\begin{array}{l}\text { Work not } \\
\text { available }\end{array}$ & $\begin{array}{l}\text { Still on } \\
\text { migration }\end{array}$ & $\begin{array}{l}\text { Other } \\
\text { reasons }\end{array}$ \\
\hline Berhampur & 5 & 1 & 6 & 2 & 38 & 6 \\
Badakul & 4 & 0 & 5 & 2 & 5 & 5 \\
\hline
\end{tabular}

I tried to understand if there was a correlation between fishers' return from migration and the reasons for which they had migrated. One may tend to think that if there were tangible factors that forced fishers to migrate, their return may have been influenced by the removal of those same factors. In other words, if a fisher had migrated due to the burden of debt then he may be inclined to return home once repayment of the debt has been done. However, careful review of Table 12 clarifies that all five factors that fishers had given as their reason for migration had remained in place as of 2015. Furthermore, the negligible earnings from migration by fisher households suggests that the levels of income from migration are so low that it is neither possible to repay their debts, compensate for the loss of income from Chilika, nor make alternate arrangements for the lack of employment opportunities locally, all of which triggered migration in the first place. In addition to the factors outlined in Table 11, there are other constraints, such as uncertainties attached to migrating to an unknown place, which restrict fishers from pursuing migration as a more long-term and reliable livelihood strategy. Despite this 39\% of the households in Berhampur stated that (as of August 2008) one or more of their family members had plans to migrate in the near future and a similar trend was recorded in 2014-2015. In contrast, only 7\% of the households in Badakul had similar plans.

Not all households are in a position to afford migration; households with many adult men are in an advantageous position compared to those with fewer adult men because women do not generally migrate. As migration often involves traveling thousands of miles outside the state boundary for unspecified periods of time, many households with single men find it difficult to opt for it as a livelihood strategy as this would mean leaving women and children behind. It was rare (7\% of households in Berhampur and 6\% of households in Badakul) that single men in a household had migrated; an indication that these households were in a desperate livelihood situation after other strategies had failed. However, households with many young men tend to rely more on migration as a livelihood strategy when compared to households with elderly men. There was no instance of migration by women or, except for one or two cases, migration with family members in both the villages. Households that are part of an extended family were found to be more migration dependant than households consisting of nuclear families.

Although only men migrated, the cost and effect of their migration on sending families were profound. In the absence of men, the household stopped fishing because culturally it

Table 12 Fishers' reason for out-migration

\begin{tabular}{lllllc}
\hline Villages & $\begin{array}{l}\text { Loss of income from } \\
\text { Chilika } \\
\text { Percentage of HH }\end{array}$ & $\begin{array}{l}\text { Burden } \\
\text { of loan }\end{array}$ & $\begin{array}{l}\text { Lack of local } \\
\text { employment }\end{array}$ & $\begin{array}{l}\text { Degradation } \\
\text { of Chilika }\end{array}$ & $\begin{array}{l}\text { Other } \\
\text { reasons }\end{array}$ \\
\hline Berhampur & 50 & 49 & 34 & 39 & 23 \\
Badakul & 17 & 17 & 11 & 13 & 13 \\
\hline
\end{tabular}

Note: Questions allowed for multiple responses 
was only men who fished. Consequently, women in the household also discontinued their fish processing chores. Thus, migration by men also contributed to the disconnection of those family members who stay behind, from their customary Lagoon resources.

\section{Discussion: outcomes of livelihood strategies}

Livelihood strategies have definitely given some respite to the fishers in the short-run. However, the long-term effectiveness of these strategies remains in question. For example, most of these strategies were initiated around the year 2004 in Berhampur and about 20 years before that time in Badakul. And yet fishers have not been able to consolidate any significant livelihood alternatives that can generate a constant source of income for them. Rather, many of these strategies have led to the further weakening of the fishery-based livelihood of fishers and, more importantly, to their own disconnect with the Lagoon. The initiation of livelihood problems occurred with changes in the Lagoon social-ecological system - changes that were largely influenced by drivers at multiple levels. Fishers across Chilika commonly viewed their livelihood strategies as a response to such changes without any long-term planning. As village leader Mayadhara Das of Badakul puts it: "a short-term approach to livelihood crisis added momentum to the pace of our own disconnection with the Lagoon instead of improving our livelihood situation." While important to highlight that aquaculture and sea mouth might have been two important drivers for the crisis in Chilika, it is equally important to mention that the impacts of livelihood intensification and expansion strategies by the fishers themselves have also contributed to this crisis. Table 13 compares the outcomes of fishers' livelihood strategies and their implications for the fishers' disconnection with the Lagoon and their marginalisation.

Key resource persons in two focus group meetings in Berhampur and Badakul confirmed that the strategies (Table 13) were primarily aimed towards addressing livelihood crisis and income generation. There was hardly any effort to build strategies to deal with the factors that caused those crises: shrimp aquaculture, sea mouth, deteriorating ecological condition of Chilika, fisher unfriendly policies, loss of key community institutions. These factors actually constituted the context, resources and institutions as described in the livelihood framework (Scoones 1998; Bebbington 1999) and changes in which had initiated a crisis in fishers' livelihoods. However, the fact that the current crisis in fishers' livelihoods was a creation of changes in context, resources and institutions did not receive attention in the formulation of livelihood strategies, thereby making their outcomes inappropriate to any long enduring resolution of the problem as well as to achieving sustainable livelihoods (Fig. 2).

Figure 2 considers that large-scale changes in the livelihood context, resources and institutions in Chilika Lagoon adversely impacted fishers' livelihood. This prompted the fishers to formulate various livelihood strategies that can be categorized under coping for subsistence, intensification, extensification, diversification and migration. However, instead of leading to positive livelihood outcomes, the resulting outcomes were far from being sustainable. Fishers in Chilika experienced quite a significant level of disconnection with the Lagoon resources that intensified the process of their marginalization through further loss of their livelihoods. Human-environment disconnection refer to "physical, psychological, economic, and political separation of people from their environment that may result from loss of access and tenure rights, loss of livelihoods, out-migration, and loss of environmental knowledge and sense of stewardship (Nayak and Berkes 2014)." 
Table 13 Outcomes of livelihood strategies and their implications for fishers' disconnection and marginalisation

Outcomes of livelihood strategies

Subsistence

Increased indebtedness

Lack of asset holding

Decline in the quality and quantity of food

High dropout from school

Decrease in high school level education

Households subscribe to a number of fish

traders

Breakdown of family support system

Politically silent

Intensification

Stop using a diversity of traditional fishing nets Dominance of Lagoon unfriendly synthetic nets Loss of knowledge to make fishing nets

No distinct season for fish, shrimps and crabs No periods of rest from fishing as previously

done

Fish breeding season dishonoured

Small sized catch not released as previously done

Fish fingerlings killed while catching post-

larval shrimp (by catch)

Overfishing of target species

Overexploitation of scarce fish resources

Pressure on already threatened levels of species composition

Disturbance in the Lagoon food chain

Chemical pollution of Lagoon waters

Limited feeding and breeding areas for fish

Lower fish stock and production

Extensification Increase in instances of inter-village conflicts

Fishing becomes capital intensive therefore expensive

Restriction in fish movement

Selective lifting affects fish stock and

composition

Disturbance in spatial distribution of fish

Encroachment of traditional fishing areas Critical fish habitats - feeding and breeding grounds - under shrimp aquaculture

Get arrested by forest and police department

Diversification Fishing to fish vending

Shift towards fresh water fish

Landlessness as a major barrier to farm-based diversification

Increase in non-fishing related occupations

Migration

High number of absent fishers (Berhampur) High number of fishers not engaged in fishing Income from migration is not financially rewarding

Family members live separately
Implications for fishers' disconnect and marginalisation

Compromise economic or financial assets

Low levels of food security

Compromise human assets

Vulnerable to exploitation by fish traders Compromise social and political capital Loss of political voice

Loss of fishing related traditional skill sets and knowledge

Dependence on market to buy fishing gears

Amplify existing fluctuations in fish seasonality

Unsustainable fishing practices with implications for future fish availability

Adverse ecological changes

Shrinkage in Lagoon fishing area

Not everyone can invest in intensive fishing

Protracted court cases with extraordinary financial implications

Not everyone can participate in such fishing

Villages deprived of access to already limited fish stock

Loss of access rights to fishing grounds

Get embroiled in police and court cases

Fishers from entrepreneurs to wage employment Move away from Lagoon fish

Not everyone engage in this activity as they do not have land

Non-fishing activities move the fishers away from the Lagoon

Physical absence from the Lagoon Long absence weakens fishing rights Young fishers find it difficult to return to fishing even if they are back in the village

Finding that livelihood strategies in Chilika could be causing harm to fishers have already been recognised by literature on livelihood adaptation, which suggest to both the positive attributes and negative connotations of adaptation strategies (Ellis 2000a, b; 


\section{Livelihoods analysis with an angle of disconnect}

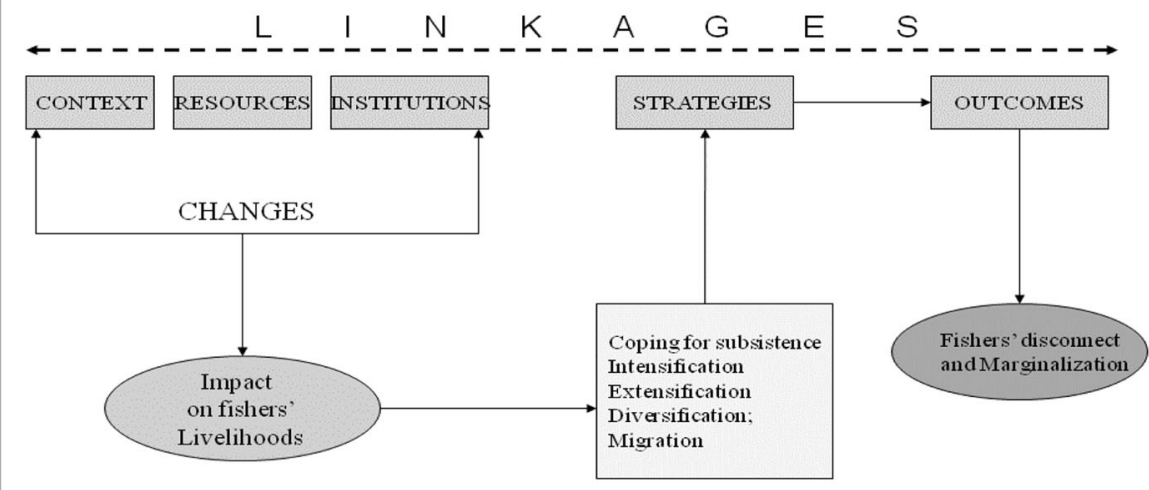

Fig. 2 Sustainable livelihood framework: Examining the strategies and outcomes (Modified from Scoones 1998; Bebbington 1999)

Hussein and Nelson 2016). Adaptation may be positive or negative. Livelihood adaptation has been defined as the continuous process of changes to livelihoods which either enhance existing security and wealth or try to reduce vulnerability and poverty (Davies and Hossain, 1997: 5). Based on this analysis and in consideration of the results from Chilika, one could conclude that livelihood strategies in Chilika have contributed to the ongoing process of fishers' disconnection and marginalization, on one hand, while failing to improve the context, resources and institutions, on the other. Therefore, the strategies used did not necessarily produce sustainable outcomes for fishers' livelihoods. Rather, most of these strategies have physically, materially and psychologically disconnected the fishers from the Lagoon. I elaborate on some of the main outcomes of fisher's livelihood strategies and discuss their implications for fishers' disconnect and marginalization (Table 14).

\section{Compromise on various assets (capitals) including the loss of social capital}

What makes repayment and the clearing of loans nearly impossible is the rate of interest and the purpose for which loans are taken. Not only are the interest rates high but the calculation of interest on the principal amount, until the entire loan is paid off, makes it difficult for fishers to clear up their loan amounts. A substantial part of the total loan is for consumption or/and other unproductive purposes. The majority of

Table 14 Key outcomes of livelihood strategies and implications for fishers disconnect and marginalisation

1. Compromise on various assets (capitals) including loss of social capital

2. Impact on Lagoon ecology and resource degradation

3. Loss of traditional skills and growing dependence on external market forces

4. Lack of commons with decline in access regimes

5. Loss of inter-household and inter-village equity

6. Livelihood diversification can disconnect too!

7. High rate of out-migration equals to large numbers of absent fishers 
these loans are from informal sources that have an interest in perpetuating the cycle of debt. This has resulted in fisher households falling into a debt trap.

For fisher households, compromise with the quality and quantity of food is rather a compulsion than a planned strategy. This has serious implications for household food security. A food culture that is predominantly based on "rice and fish" is fast changing into a situation where a significant number of households now eat less of both. A change of food habit from eating lagoon fish, which fishers never had to buy, to regularly eating potatoes or occasional fresh water fish, which they have to pay for, is becoming common in households. The obvious fallout of these changes is on the health status of fisher families, which is in constant decline. Fisher households now tend to spend more on health and hospitalisation. Moreover, these changes signify a move from the earlier resource dependence to cash dependent household economies. This trend may not be viable in an already cash strapped marginalized society. Low levels of education due to high dropout rates from school restrict the future possibility of fisher children taking up mainstream jobs. In a society that is divided on caste and class lines, low levels of education can bring further exclusion to groups that are already on the margins.

Even though more fish traders mean a higher availability of interest-free advances, such arrangements make the fishers vulnerable to further exploitation at the hands of the fish traders. Under the arrangements, fishers are forced to sell their produce to traders even though it may fetch better prices elsewhere. Moreover, prices offered by traders further bring down the profit level for the fishers. The practice of cutback or commission, ranging from 2 to 20 INR per kilogram of fish (depending on the type of fish), brings prices further down. As such, the relationship between fishers and traders is in itself a factor for marginalization, and fisher households subscribing to multiple traders go through this even more intensely. Table 15 outlines the strings attached to the cash advances offered by the fish traders. In many cases, the fish trader has taken away fishers' boats as the advance money could not be returned. In other cases, fish traders have threatened to take away fishing boats if the advance money is not returned.

There has also been a breakdown in the family support system as livelihood crisis is seeing the prevalence of the nuclear family instead of the extended family system; a strategy taken up by many households to minimize the impact of livelihood crisis on bigger families. A continued crisis situation and fishers' particular focus on livelihood alternatives has resulted in their withdrawal from public life, an

Table 15 Receiving an advance from the fish buyer

\begin{tabular}{ll}
\hline Conditions of Advance & Strings attached \\
\hline $\begin{array}{l}\text { Obligation to see only to the } \\
\text { trader }\end{array}$ & The fisher is obliged to sell fish only to the trader who provides the advance \\
$\begin{array}{ll}\text { Short-changed on weight } \\
\text { Short-changed on price }\end{array}$ & $\begin{array}{l}\text { Mostly pre-determined price or a price often lower than the highest available } \\
\text { market price }\end{array}$ \\
$\begin{array}{l}\text { Commission } \\
\text { Shrimp 10-20; Fish 7-10; Small fish and shrimp 2-5; Crab - variable rates (All prices } \\
\text { in INR) }\end{array}$ \\
Violation of any of the conditions result in immediate return of the advance
\end{tabular}


indication that more and more fishers are becoming politically silent and may be in a process of losing their political voice.

\section{Impact on Lagoon ecology and resource degradation}

The outcomes of intensification and extensification strategies have directly impacted the ecology of the Lagoon and brought further degradation in resource condition; a factor that is potentially strong in bringing down the quality of lives of the resource dependent poor. A set of intensification strategies resulted in the alteration of fish seasonality, lack of attention to the fish breeding periods, bringing key fish habitats under exhaustive fishing activities, all of which contributed to an amplification of the existing fluctuations in fish environments. Fishing behaviours changed to capture fish of all sizes by forgoing the customary norm of releasing small sized catch; destroying more numbers of post-larval fish while picking post-larval shrimp for aquaculture ponds; overfishing target species and overexploiting scarce fish resources at the cost of impacting fish stock and production. Such outcomes exerted pressure on species composition, altered the spatial distribution of fish, and disturbed the Lagoon food chain. Thus intensification in Chilika has led to a situation of "fishing down the food chain" (Pauly et al. 1998), ultimately contributing to adverse ecological changes. Such a link between overfishing and fishing related livelihood strategies (mainly intensification and expansion) has been shown elsewhere by Neis and Kean (2003). This study emphasises that ecological degradation has a tendency to disconnect the population that depends on it for livelihoods.

\section{Loss of traditional skills and growing dependence on external market forces}

Customary techniques used by the fishers were based on caste, season, species and specific to fishing locations within the Lagoon. A diversity of fishing nets were locally made by the fishers and used to support customary fishing practices. With intensification, there was a significant change in the traditional fishing methods and techniques that were gradually replaced with synthetic gill nets and trammel nets. As an outcome, fishers stopped using a diversity of fishing nets and, more importantly, stopped making them locally. Instead, they grew dependent on the market for buying synthetic nets, which most fishers found difficult in a cash strapped local economy. Moreover, communities experienced a steady loss of fishing related traditional skill sets; specifically the knowledge to prepare a variety of fishing gears that were socially and ecologically appropriate. Thus, in Chilika, growing dependence on external market forces and the loss of traditional skills contributed to the process of disconnection of fisher communities from the Lagoon.

The outcomes of uninterrupted aquaculture consistently impacted the Lagoon ecosystem and its interlinked social structures. This was evident as shrimp aquaculture activities, used both as intensification and extensification strategies, had multiple social-ecological influences on the level of fishers' disconnection and marginalization. In response to the survey question on - Are you experiencing any adverse impacts of shrimp aquaculture either on the Lagoon or on your fishing activities, or both? - 135 fisher villages in Chilika replied that they were adversely impacted. On one hand, it has led to chemical pollution in the Lagoon and the encroachment of important fish 
habitats thereby limiting the fish feeding and breeding grounds, and affecting fish stock and catch size. On the other hand, aquaculture has resulted in shrinkage of the Lagoon fishing area through encroachment, which has led to serious concerns over fishers' access to both the scarce fish stock and fishing areas (Nayak and Berkes 2011). More than $70 \%$ of fisher villages reported loss of customary fishing areas, ranging from 10 to 100\% of the total area, to encroachment by powerful shrimp mafias. Thus, aquaculture led class exploitation was in itself a form of marginalization.

\section{Lack of commons with decline in access regimes}

In addition to encroachment, extensification strategies have pushed fishers beyond their customary fishing boundaries and initiated competition for capturing strategic fishing areas, all of which have contributed to an overall increase in the instance of intervillage conflicts. Several villages are now enmeshed in prolonged court cases; villages borrow money, often through sub-lease of fishing areas to shrimp aquaculture owners, in order to pursue these legal disputes. Villages like Satapada and Kumarpur have debts to the tune of US \$200,000 each, a phenomenon common to several fisher villages across Chilika. Fisher villages largely disregard once agreed-upon boundary rules that had laid the foundation for commons formation in Chilika; a situation indicative of an open access regime and a trend towards the decommonisation of fishery resources in Chilika (Nayak and Berkes 2011). These outcomes suggest that a lack of commons status with the decline in access regimes has led to the marginalisation of fishers.

\section{Loss of inter-household and inter-village equity}

Outcomes of both intensive and extensive fishing strategies have also resulted in serious implications for inter-household equity issues. Consequent to these strategies, fishing has become capital intensive, and therefore expensive, leading to the exclusion of several poor households from fishing. This has increased the gap between rich and poor in the villages resulting in the further marginalization of poorer households. This gap is further widened by the lack of options for poor households to diversify their livelihood activities. Landlessness, a status affecting more than $83 \%$ of households in both study villages, emerged as a major barrier to farm-based livelihood diversification. While households with land assets tried to use available natural capital through cultivation and plantations, the landless poor could not do so. These households also find it difficult to diversify into other non-fishing activities due to the absence of financial capital that is available to some well-off households. As a result, while the richer households tried to initiate a small business as part of their diversification strategy, the poorer households in the two villages have primarily gone into daily wage, including migration. Therefore, growing equity concerns as a result of various livelihood strategies are emerging as factors for marginalization of Chilika fishers.

\section{Livelihood diversification can disconnect too!}

While fewer options for livelihood diversification can make households prone to getting marginalised, a somewhat similar trend was also observed in cases where households did diversify their livelihood activities to a number of fishing and non-fishing occupations. In the case of Prasant Behera and his wife Jyanti Behera of Badakul, the move 
from fishing to fish vending signifies a change from being an entrepreneur to accepting a form of wage employment. They consider this as a form of disconnect from the Lagoon. Since a number of fisher women (fish vendors) now sell fresh water fish bought from the central fish market their chances of staying connected to the Lagoon is gradually decreasing. Hajari Behera of Badakul, whose household has taken up both migration and seasonal jobs as a boat driver, sees these non-fishing activities as pushing them away from the Lagoon, a form of disconnect that is resulting in their physical separation from "mother Chilika." Both Prasant and Hajari are apprehensive about their continued existence in the new occupations. As caste-based fishers, they think that livelihood activities other than fishing would soon disengage them from the Lagoon.

Studies elsewhere have shown that diversification is a desired strategy that could help in situations of livelihood crisis (Marschke 2005; Ta 2010). However, livelihood diversification becomes impossible in the absence of various capitals, most importantly natural and financial capitals, and it may produce only limited results. In resource dependent poor communities, diversification requires continuous government support in terms of income generating programmes as well as the protection of fishers' access to the resource through appropriate policy provisions. Successful diversification of livelihood activities could potentially curb the ever increasing influence of extensification and intensification in Chilika, apart from having a positive impact on the trend in migration.

\section{High rate of migration leads to large numbers of absent fishers}

A high rate of migration equates to a large number of absent fishers in the villages. This physical absence of fishers from the Lagoon is a leading form of disconnect that may have lasting future implications. Fishers fear that such long absence from the Lagoon may eventually weaken their fishing rights not only as individual or household right-holders but their stake in the Lagoon as a collective. Since incomes from migration are not particularly rewarding, the "poor" status of fishers and their livelihood conditions (prior to their migration) either remains unchanged or worsens further. The level of disconnect is intense in the case of young fishers who find it difficult to return to fishing even if they are back in the village and no longer planning to migrate.

\section{Conclusions: Sustainable livelihoods in theory and practice}

The livelihoods approach offers a basis for extensive analysis of fishers' livelihood crisis, strategies, outcomes and future scenarios. Livelihoods can be understood as "the assets (natural, physical, human, financial and social capital), the activities (strategies of use), and the access to these (mediated by institutions and social relations) that together determine the living gained by the individual and the household" (Ellis 2000a, b: 10). The multiplicity of ways through which fishers in Chilika perceive their livelihood, challenges the dominant view that the concept of livelihood is about economic activities and incomes. It suggests that livelihoods in resource dependent communities, such as Chilika small-scale fisheries, are far more complex and dynamic. Chambers (1995) observed that "the realities of poor people are local, complex, diverse and dynamic." For many of the poor, livelihood seems to fit better than employment as a concept to capture how poor people live, what their realistic priorities are, and what can help them. 
"Sustainable" then refers to the longer-term and "livelihood" to the many activities which make up a living. It is a "highly complex, all-encompassing concept, which is not restricted to the ecological or to the economic or productive aspects of life" (De Haan and Zoomers 2003:350). Therefore, encapsulating the diversity and complexity of how people make a living is challenging (Marschke 2005:121). It is about individuals, households, or groups making a living, attempting to meet their various consumption and economic necessities, coping with uncertainties, and responding to new opportunities (De Haan and Zoomers 2003). Individual and household livelihoods are shaped by local and distant institutions, social relations, and economic opportunities (Ellis 2000a, b: 6). In the context of Chilika livelihoods and their related activities are best understood as a "way of life" (Rigg 2005; Nayak and Berkes 2011).

Literature on livelihood tend to be divided on the question of sustainable outcomes. It is already recognized that livelihood adaptation may lead to positive or negative outcomes (Davies and Hossain, 1997). However, there is significant focus in the literature on ways in which livelihoods can be made sustainable (Scoones 1998; Marschke and Berkes 2006; Allison and Horemans 2006). Chilika study suggests that sustainable outcomes are not always the case when livelihood strategies are used. Instead, possibilities of unsustainable outcomes such as human-environment disconnection and marginalisation remains quite high. As Carswell (1997:10) points out: definitions of sustainable livelihoods are often unclear, inconsistent and relatively narrow. Without clarification, there is a risk of simply adding to a conceptual muddle. Scoones' (1998:5) observation that "the growing body of literature is not particularly clear on the question of what a sustainable livelihood is" complements this. Also, the existing literature provides little clarity about how contradictions between wide sets of issues and relationships are addressed and trade-offs are assessed. Nevertheless, the core principles of the approach have been widely adopted and as an analytical tool or way of thinking about the causes of poverty it has been influential (Neiland and Béné 2004; Andrew et al. 2007).

Recent work has focused on various factors that potentially contributes to an enhanced understanding of livelihoods including shocks and stresses (De Haan 2000; De Haan and Zoomers 2003, 2005); fluctuations in resource status and dynamics linked to resource use and access (Marschke and Berkes 2006); drivers at multiple scales that influence livelihood context (MEA 2003, 2005; Nayak et al. 2014); impacts of interactions between global and local forces and contexts (Armitage and Johnson 2006; Nayak and Berkes 2014); influence of poverty on livelihoods (Bebbington 1999; Béné 2003); use of resilience (Hanazaki et al. 2013; Coulthard 2012) and well-being (White and Ellison 2007; Coulthard et al. 2011; Weeratunge et al. 2014) and help clarify the many challenges of making livelihoods sustainable. Despite such scholarly progress a complete understanding of the processes and mechanisms leading to sustainable livelihoods still remains work in progress, and there is a gap in the literature. The empirical data and analytical perspectives presented in this paper, using the case of small scale fisherybased livelihood system of Chilika Lagoon, contributes to the bridging of this gap.

\section{Endnotes}

${ }^{1}$ As a general ethical principle, pseudonyms have been used for all women fishers to be compatible with local cultural practices and as a measure of extra care given the sensitivities associated with issues of women in a conservative rural Odiya society. With 
regard to male fishers, a mix of real names and pseudonyms have been used under the proviso that verbal consent was received in all cases where real names have been used. The men in the fisher society, especially those in village and regional leadership positions, prefer to have their names associated with their statements, and I have honoured this. However, I have taken particular care to protect those fishers who may be vulnerable by applying the principle of anonymity and the use of pseudonyms.

${ }^{2}$ The Mid-day Meal Scheme is the popular name for school meal programme in India. With a view to enhancing enrollment, retention and attendance and simultaneously improving nutritional levels among primary school children in grades 1 to 5 , the National Programme of Nutritional Support to Primary Education (NP-NSPE) was launched as a Centrally (Federally) Sponsored Scheme in 1995 which covers all the development blocks in India. The scheme involves provision of lunch free of cost to school children on all working days.

${ }^{3}$ Deepak's words indicate that there is a "tragedy of the commons" situation in the Lagoon as disappearance of seasonality is a symptom of a bigger issue of open access or the disappearance of rules of conduct.

\section{Acknowledgements}

Support for the 2007-2009 livelihood surveys came through a doctoral scholarship from the Pierre Elliott Trudeau Foundation of Canada to Prateep Nayak. Additional funding was made available by the Canada Research Chair in Community-Based Resource Management held by Prof. Fikret Berkes. Recent data collection between 2012 and 2016 in Chilika Lagoon have been supported by funding from the Social Sciences and Humanities Research Council (SSHRC) of Canada. I would like to thank the fishers of Chilika Lagoon for their unconditional friendship, support, and collaboration over the last more than a decade. This manuscript has benefited from the constructive comments made by Barbara Neis (Memorial University, Canada), Fikret Brekes, Emdad Haque and lain Davidson-Hunt (all three from University of Manitoba, Canada) on an earlier draft. I also thank the two anonymous reviewers for their thoughtful and very helpful comments.

Funding

There are no specific funding agencies to be recognised for this manuscript.

\section{Authors' contributions}

PN is the sole author of this manuscript and he was responsible for data collection, data processing and writing of this manuscript.

\section{Authors' information}

Prateep has an academic background in political science, environmental studies and international development. He has a PhD in Natural Resources and Environmental Management from University of Manitoba, Canada. He does interdisciplinary work with an active interest in combining social and ecological perspectives. Prateep's research focuses on the understanding of complex human-environment connections (or disconnections) with particular attention to change, its drivers, their influence and possible ways to deal with them. In the past, Prateep worked as a development professional in India on issues around community-based governance of land, water and forests, focusing specifically at the interface of research, implementation and public policy. Currently, Prateep is an Assistant Professor in the School of Environment, Enterprise and Development of University of Waterloo, Canada.

\section{Competing interests}

The author declares that he has no competing interests.

Received: 23 September 2016 Accepted: 7 June 2017

Published online: 15 November 2017

\section{References}

Adger, WN, PM Kelly, A Winkels, LQ Huy, C Locke. 2002. Migration, remittances, livelihood trajectories, and social resilience. Ambio 31(4): 358-366 DOl: http://dx.doi.org/10.1579/0044-7447-31.4.358.

Adduci, M. 2009. Neoliberal wave rocks Chilika Lake, India: conflict over intensive aquaculture from a class perspective. Journal of Agrarian Change 9(4): 484-511. doi:10.1111/j.1471-0366.2009.00229.x.

Allison, EH, B Horemans. 2006. Putting the principles of the sustainable livelihoods approach into fisheries policy and practice. Marine Policy 30: 757-766.

Andrew, NL, C Béné, et al. 2007. Diagnosis and management of small-scale fisheries in developing countries. Fish and Fisheries 8(3): 227-240.

Armitage, D, D Johnson. 2006. Can resilience be recognized with globalization and increasingly complex resource degradation in Asian coastal regions? Ecology and Society 11(1): 2 Online at: http://www.ecologyandsociety.org/ vol11/iss1/art2/. 
Bebbington, A. 1999. Capitals and capabilities: a framework for analysing peasant viability, rural livelihoods and poverty. World Development 27(12): 2021-2044.

Béné, C. 2003. When fishery rhymes with poverty: a first step beyond the old paradigm on poverty in small-scale fisheries. World Development 31(6): 949-975

Béné, C. 2005. The good, the bad and the ugly: discourse, policy controversies, and the role of science in the politics of shrimp farming development. Development Policy Review 23(5): 585-614.

Sahu, BK, P Pati, RC Panigrahy. 2014. Environmental conditions of Chilika Lake during pre and post hydrological intervention: an overview. Journal of Coastal Conservation 18(3): 285-297. doi:10.1007/s11852-014-0318-z.

Carswell, G.1997 Agricultural intensification and sustainable rural livelihoods: a think piece, IDS Working Paper 64. Brighton: IDS.

Carswell, G. 2002. Livelihood diversification: Increasing in importance or increasingly recognized? Evidence from southern Ethiopia. Journal of International Development 14(6): 789-804. doi:10.1002/jid.924.

Chambers, R. 1995. Poverty and livelihoods: Whose reality counts? Environment and Urbanization 7: 173-204

Chambers, R, G Conway.1992 Sustainable rural livelihoods: Practical concepts for the 21st century, Institute of Development Studies Discussion Paper 296. Brighton: Institute of Development Studies.

Cinner, JE, Ö Bodin. 2010. Livelihood diversification in tropical coastal communities: a network-based approach to analyzing 'livelihood landscapes'. PloS One 5(8): e11999. doi:10.1371/journal.pone.0011999.

Coulthard, S. 2012. Can we be both resilient and well, and what choices do people have? Incorporating agency into the resilience debate from a fisheries perspective. Ecology and Society 17(1): 4 http://dx.doi.org/10.5751/ES-04483-170104

Coulthard, S, D Johnson, JA McGregor. 2011. Poverty, sustainability and human wellbeing: a social wellbeing approach to the global fisheries crisis. Global Environmental Change 21: 453-463 http://dx.doi.org/10.1016/j.gloenvcha.2011.01.003.

Davies, S, N Hossain.1997 Livelihood adaptation, public action and civil society: a review of the literature, IDS working paper 57. Brighton: IDS.

De Haan, L. 2000. Globalisation, localisation and sustainable livelihoods. Sociologia Ruralis 40(3): 339-365.

De Haan, L, A Zoomer. 2003. Development geography at the crossroads of livelihood and globalisation. Tijdschrift voor Economische en Sociale Geografie 94(3): 350-362.

De Haan, L, A Zoomers. 2005. Exploring the frontier of livelihoods research. Development and Change 36(1):27-47.

De Haan, A. 1999. Livelihoods and poverty: the role of migration - a critical review of the migration literature. The Journal of Development Studies 36(2): 1-47 http://dx.doi.org/10.1080/00220389908422619.

Delgado, CL, N Wada, MW Rosegrant, S Meijer, M Ahmed.2003 Outlook for fish to 2020: meeting global demand. Washington DC: International Food Policy Research Institute and Penang and WorldFish Center.

Dujovny, E. 2009. The deepest cut: political ecology in the dredging of a New Sea mouth in Chilika Lake, Orissa, India. Conservation and Society 7: 192-204.

Ellis, F.2000a Rural livelihoods and diversity in developing countries. Oxford: Oxford.

Ellis, F. 2000b. The determinants of rural livelihood diversification in developing countries. Journal of Agricultural Economics 51(2): 289-302. doi:10.1111/j.1477-9552.2000.tb01229.x.

Eneyew, A, W Bekele. 2012. Determinants of livelihood strategies in Wolaita, southern Ethiopia. Agricultural Research and Reviews 1(5): 153-161.

Fabinyi, M. 2010. The intensification of fishing and the rise of tourism: competing coastal livelihoods in the Calamianes Islands, Philippines. Human Ecology 38: 415-427. doi:10.1007/s10745-010-9329-z.

Food and Agriculture Organisation. 2006. FishStat plus. Online at: http://www.fao.org/fi/statist/fisoft/fishplus.asp.

Gebrehiwot WG, F Beyene. 2012. Rural household livelihood strategies in drought-prone areas: a case of Gulomekeda District, eastern zone of Tigray National Regional State, Ethiopia. Journal of Development and Agricultural Economics 4(6): 158-168. doi:10.5897/JDAE12.026.

Hanazaki, N, F Berkes, CS Seixas, N Peroni. 2013. Livelihood diversity, food security and resilience among the Caiçara of coastal Brazil. Human Ecology 41(1): 153-164.

Karim H, J Nelson. 1998. Sustainable livelihoods and livelihood diversification. IDS Working Paper 69. Sussex, UK

Kurien, J. 1992. Ruining the commons and responses of the commoners: Coastal overfishing and fishermen's actions in Kerala state, India. In Grassroots environmental action: Peoples participation in sustainable development. D Ghai, J Vivian, editors, 221-258. London: Routledge.

Miyuki I, P Kariuki, P Kristjanson, S Kaitibie, J Maitima. 2007. Livelihood diversification strategies, incomes and soil management strategies: a case study from Kerio Valley, Kenya. 20(3): 380-397. DOl: 10.1002/jid.1419

Marschke, M. 2005. Livelihood in context: Learning with Cambodian fishers. Thesis (PhD). University of Manitoba, Canada

Marschke, MJ, F Berkes. 2006. Exploring strategies that build livelihood resilience: a case from Cambodia. Ecology and Society 11(1): 42 Online at: http://www.ecologyandsociety.org/vol11/iss1/art42/.

Marshall, J. 2001. Landlords, leaseholders, and sweat equity: Changing property regimes in aquaculture marine policy 25: $335-352$

MEA (Millennium Ecosystem Assessment). 2005. Ecosystems and human well-being: General synthesis. In: Millennium Ecosystem Assessment. Chicago, IL, USA: Island Press. Online at: http://www.Millenniumassessment.org/en/Synthesis.aspx.

MEA (Millennium Ecosystem Assessment). 2003 Ecosystems and human well-being: A framework for assessment. Chapter 5: Dealing with scale. In Millennium Ecosystem Assessment. Washington DC: Island Press.

Nayak, PK. 2011 Conditions for Governance of tenure in lagoon social-ecological systems: Lessons from around the world, UN/FAO initiative on governance of tenure for responsible capture fisheries. Rome: FAO.

Nayak, PK, F Berkes. 2010. Whose marginalisation? Politics around environmental injustices in India's Chilika lagoon. Local Environment 15(6): 553-567 http://dx.doi.org/10.1080/13549839.2010.487527.

Nayak, PK, F Berkes. 2011. Commonisation and decommonisation: understanding the processes of change in Chilika lagoon, India. Conservation and Society 9(2): 132-145 doi:10.4103/0972-4923.83723.

Nayak, PK. 2014. The Chilika lagoon social-ecological system: an historical analysis. Ecology and Society 19(1): 1 http:// dx.doi.org/10.5751/ES-05978-190101.

Nayak, PK, F Berkes. 2014. Linking global drivers with local and regional change: a social-ecological system approach in Chilika lagoon, bay of Bengal. Regional Environmental Change 14(6): 2067-2078 doi:10.1007/s10113-012-0369-3. 
Nayak, PK, LE Oliveira, F Berkes. 2014. Resource degradation, marginalization, and poverty in small-scale fisheries: threats to social-ecological resilience in India and Brazil. Ecology and Society 19(2): 73 http://dx.doi.org/10.5751/ES-06656-190273.

Nayak, PK, D Armitage, M Andrachuk. 2015. Power and politics of social-ecological regime shifts in the Chilika lagoon, India and Tam Giang lagoon, Vietnam. Regional Environmental Change Online First: 10.1007/s10113-015-0775-4

Neiland, AE, C Béné, editors.2004 Poverty and small-scale fisheries in West Africa. Rome: FAO.

Neis, B, R Kean. 2003. Why fish stocks collapse. In Retrenchment and regeneration in rural Newfoundland. R Byron, editor, 65-102. Toronto: University of Toronto Press.

Neiland, AE, N Soley, JB Varley, DJ Whitmarsh. 2001. Shrimp aquaculture: economic perspectives for policy development. Marine Policy 25: 265-279.

Orr, A, B Mwale. 2001. Adapting to adjustment: smallholder livelihood strategies in Southern Malawi. World Development 29(8): 1325-1343 http://doi.org/10.1016/S0305-750X(01)00042-0.

Pauly, D, V Christensen, J Dalsgaard, R Froese, F Torres. 1998. Fishing down marine food webs. Science 279: 860-863.

Pattanaik, S. 2007. Conservation of environment and protection of marginalized fishing communities of Lake Chilika in Orissa, India. Journal of human ecology 22(4): 291-302.

Pradhan, D, M Flaherty. 2008. National initiatives, local effects: trade, liberalization, shrimp aquaculture, and coastal communities in Odisha, India. Society and Natural Resources 21: 63-76.

Raut, N, BK Sitaula, RM Bajracharya. 2010. Agricultural intensification: linking with livelihood improvement and environmental degradation in Mid-Hills of Nepal. Journal of Agriculture and Environment 11: 83-94.

Rigg, J. 2005. Poverty and livelihoods after full-time farming: a South-East Asian view. Asia Pacific Viewpoint 46(2): 173-184.

Robson, JP, PK Nayak. 2010. Rural out-migration and resource dependent communities: lessons from Mexico and India. Population and Environment 32: 263-284.

Samal, KC. 2007. Poverty, Social Capital and Natural Resource Management. New Delhi, India: Rawat Publications.

Sekhar, NU. 2004. Fisheries in Chilika lake: How community access and control impacts their management. Journal of Environmental Management 73: 257-266.

Scoones, I. 1998 Sustainable rural livelihoods: A framework for analysis, IDS Working Paper 72. Brighton: Institute of Development Studies.

Thieme, S. 2008. Sustaining livelihoods in multi-local settings: Possible theoretical linkages between transnational migration and livelihood studies. Mobilities 3(1): 51-71. doi:10.1080/17450100701797315.

Tomich, T, M van Noordwijk, S Budidarsono, A Gillison, T Kusumanto, D Murdiyarso, F Stolle, AM Fagi. 2000. Agricultural intensification, deforestation, and the environment: Assessing tradeoffs in Sumatra, Indonesia. In Tradeoffs and synergies: Agricultural intensification, economic development and the environment. D Lee, C Barrett, editors, 221244. Wallingford: CAB International.

Tuyen, TV, D Armitage, M Marschke. 2010. Livelihoods and co-management in the tam Giang lagoon, Vietnam. Ocean and Coastal Management 53(7): 327-335. doi:10.1016/j.ocecoaman.2010.04.001.

Ta, TTH. 2010 Resource access and livelihood resilience in tam Giang Lagoon, Vietnam. Thesis (PhD). Canada: University of Manitoba.

Waddington, C. 2003. Livelihood outcomes of migration for poor people. Working Paper T1. Brighton: Sussex Centre for Migration Research, University of Sussex URL: www.migrationdrc.org/publications/working_papers/WP-T1.pdf.

Weeratunge, N, C Bene, R Siriwardane, A Charles, D Johnson, EH Allison, PK Nayak, M Badjeck. 2014. Small-scale fisheries through the wellbeing lens. Fish and Fisheries 15(2): 255-279.

White, S. M Ellison. 2007. Well-being, livelihoods and resources in social practice. In Well-being in developing countries: From theory to research. I Gough, JA McGregor, editors, 157-175. Cambridge: Cambridge University Press.

\section{Submit your manuscript to a SpringerOpen ${ }^{\circ}$ journal and benefit from:}

- Convenient online submission

- Rigorous peer review

Open access: articles freely available online

- High visibility within the field

- Retaining the copyright to your article

Submit your next manuscript at $\gg$ springeropen.com 